\title{
Alkaline Etch System Qualification
}

Federal Manufacturing \& Technologies

S. E. Goldammer,

S. E. Pemberton, and

D. R. Tucker

KCP-613-5917

Published April 1997

Topical Report

Approved for public release; distribution is unlimited.

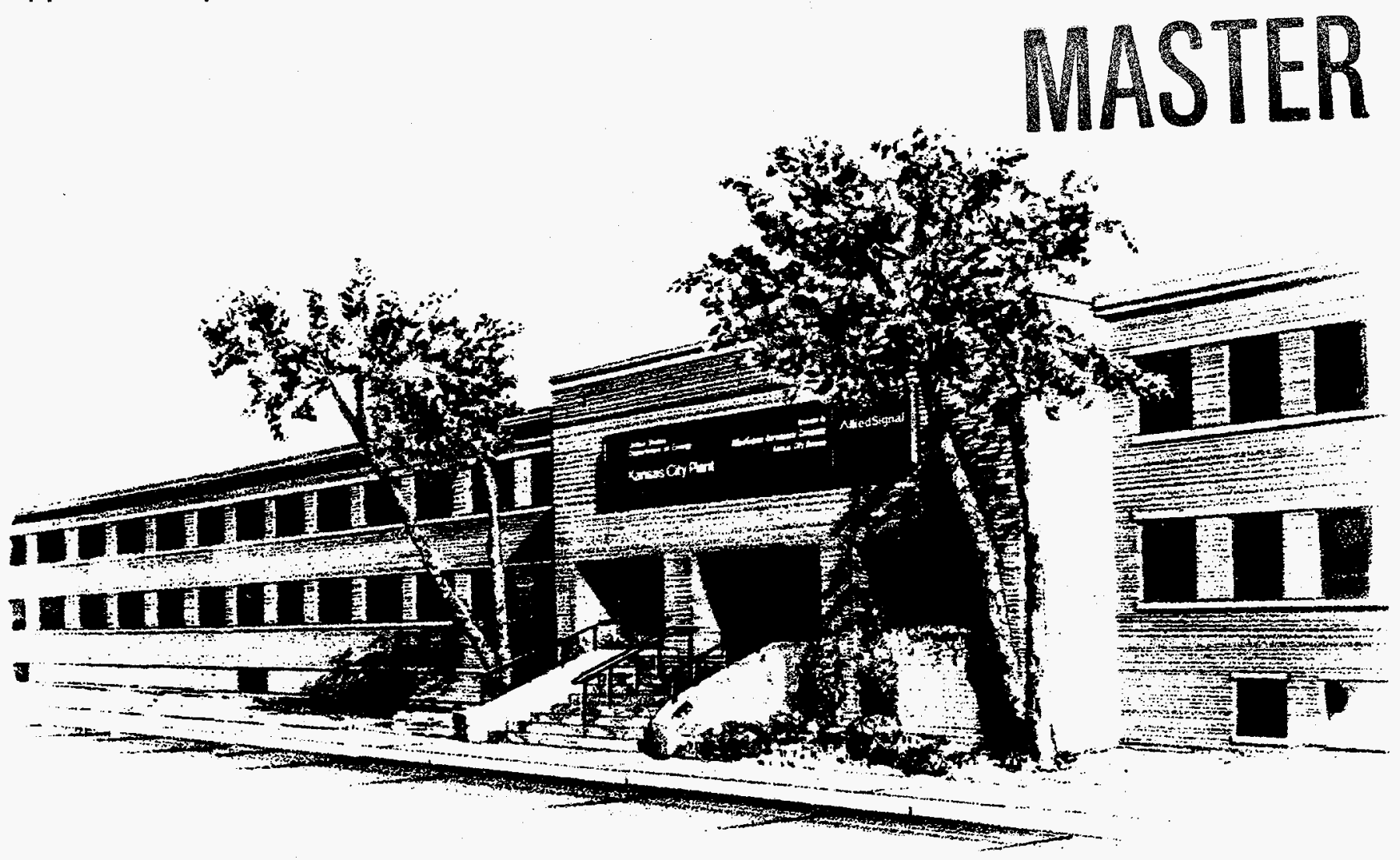




\section{DISCLAIMER}

This report was prepared as an account of work sponsored by an agency of the United States Government. Neither the United States Government nor any agency thereof, nor any of their employees, makes any warranty, express or implied, or assumes any legal liability or responsibility for the accuracy, completeness, or usefulness of any information, apparatus, product, or process disclosed, or represents that its use would not infringe privately owned rights. Reference herein to any specific commercial product, process, or service by trade names, trademark, manufacturer, or otherwise, does not necessarily constitute or imply its endorsement, recommendation, or favoring by the United States Government or any agency thereof. The views and opinions of authors expressed herein do not necessarily state or reflect those of the United States Government or any agency thereof.

All data prepared, analyzed and presented has been developed in a specific context of work and was prepared for internal evaluation and use pursuant to that work authorized under the referenced contract. Reference herein to any specific commercial product, process or service by trade name, trademark, manufacturer, or otherwise, does not necessarily constitute or imply its endorsement, recommendation, or favoring by the United States Government, any agency thereof or AlliedSignal Inc.

Printed in the United States of America.

This report has been reproduced from the best available copy.

Available to DOE and DOE contractors from the Office of Scientific and Technical Information, P. O. Box 62, Oak Ridge, Tennessee 37831; prices available from (615) 576-8401, FTS 626-8401.

Available to the public from the National Technical Information Service, U. S. Department of Commerce, 5285 Port Royal Rd., Springfield, Virginia 22161.

A prime contractor with the United States Department of Energy under Contract Number DE-ACO4-76-DP00613.

\author{
AlliedSignal Inc. \\ Federal Manufacturing \\ \& Technologies \\ P. O. Box 419159 \\ Kansas City, Missouri \\ 64141-6159
}




\section{DISCLAIMER}

This report was prepared as an account of work sponsored by an agency of the United States Government. Neither the United States Government nor any agency thereof, nor any of their employees, make any warranty, express or implied, or assumes any legal liability or responsibility for the accuracy, completeness, or usefulness of any information, apparatus, product, or process disclosed, or represents that its use would not infringe privately owned rights. Reference herein to any specific commercial product, process, or service by trade name, trademark, manufacturer, or otherwise does not necessarily constitute or imply its endorsement, recommendation, or favoring by the United States Government or any agency thereof. The views and opinions of authors expressed herein do not necessarily state or reflect those of the United States Government or any agency thereof. 


\section{DISCLAMMER}

Portions of this document may be illegible in electronic image products. Images are produced from the best available original document. 
KCP-613-5917

Distribution Category UC-706

Approved for public release; distribution is unlimited.

\author{
ALKALINE ETCH SYSTEM QUALIFICATION \\ S. E. Goldammer, \\ S. E. Pemberton, and \\ D. R. Tucker
}

Published April 1997

Topical Report 


\section{Contents}

Section

Page

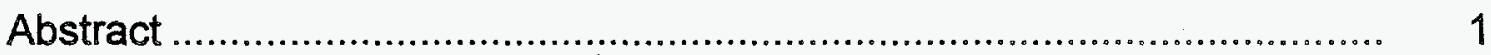

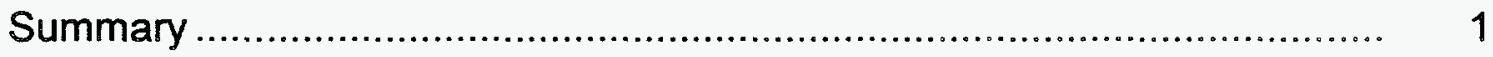

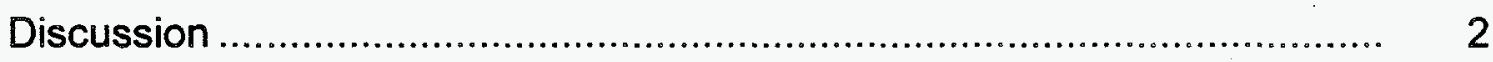

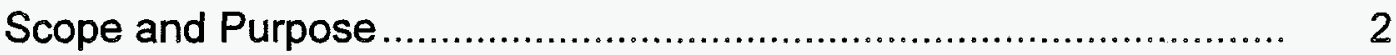

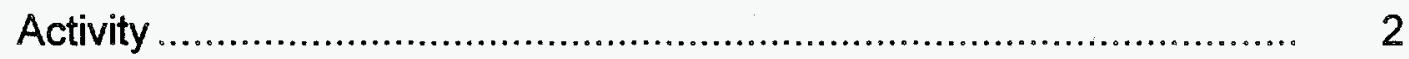

Background ..................................................................... 2

Qualification Activity ......................................................... 2

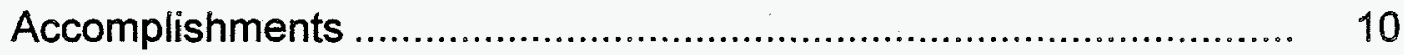

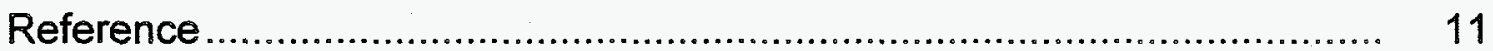

Appendix. Processing Sequence and Parameters ............................... 12 


\section{Illustrations}

Figure

Page

1 Artwork Used to Image Patterns.....................................................

2 Uniformity of Top and Bottom Conductor Widths ............................ 4

3 Difference in Average Top and Bottom Conductor Widths............... 5

4 SEM of Conductor Sidewalls Etched in the Chemcut System............ 6

5 SEM of Conductor Sidewalls Etched in the Atotech System ............... 6

6 Cross Section of Conductors Etched in the Chemcut System............. 7

7 Cross Section of Conductors Etched in the Atotech System.............. 7

8 Chloride Ion Residue ............................................................... 8

9 Amount of Etch Begining With 0.006" Line ..................................... 8

10 Yields of the $0.006^{\prime \prime}$ Lines (Opens) and 0.0055" Spaces (Shorts) ...... 9 


\begin{abstract}
A new alkaline etch system was qualified for printed wiring board fabrication. The system was a horizontally conveyorized spray system.
\end{abstract}

\title{
Summary
}

Based on the data from this qualification activity, the Atotech etch system, even with minimum characterization, was capable of etching production printed circuit products as good as those from the Chemcut system. Further characterization of the Atotech system will improve its etching capability.

In addition to the improved etch quality expected from further characterization, the Atotech etch system has additional features that help reduce waste and provide for better consistency in the etching process. The programmable logic controller and computer will allow operators to operate the system manually or from pre-established recipes. Some of the additional features are as follows.

- Processing data can be easily stored and retrieved.

- Cascading rinses in the Atotech system will use less water for rinsing and therefore produce less waste water.

- In the automatic mode, the rinses and other components automatically shut off if the system sensors do not detect panels being run after a given time period, which also reduces waste.

- The specific gravity and pH sensors/controllers provide for a more stable etch solution.

- Etch chemistry filtration is improved to reduce nozzle clogging.

The evidence and capabilities of the Atotech system made it "as good as" or "better" than the Chemcut system for etching WR products. The Printed Wiring Board Engineering Department recommended that the Atotech system be released for production. In December 1995, the Atotech system was formerly qualified for production. 


\section{Discussion}

\section{Scope and Purpose}

This work was necessary to qualify a new alkaline etch system for production use. The etcher was purchased to replace an existing etcher.

\section{Activity}

\section{Background}

The alkaline etch system was purchased from the Chemcut Group of Atotech USA Inc. (formerly Chemcut) for etching printed wiring products in the Printed Circuit Boards Fabrication Department. The system was installed in the summer of 1994. An engineering evaluation release included a qualification plan for the etch system. Qualification and characterization activities began in August 1994. The system was down for repairs between November 1994 and June 1995. During this time, the qualification plan was revised to take advantage of a new testing technology which uses measurements of electrical properties of several conductor patterns to establish yields and determine conductor line and space dimensions. The revised plan was approved in a revised engineering evaluation release on June 21, 1995.

\section{Qualification Activity}

Panels etched on the Atotech (new etch system) were compared to panels etched on the Chemcut (old etch system) to determine if the new Atotech etch system was capable of being used for production products. Both etchers were horizontal conveyorized systems. The same etch chemistries were used in both systems; MacDermid's Ultra Etch makeup solution was used in the etch sump, MacDermid's Ultra Etch 50 was used to replenish the makeup solution, and MacDermid's Ultra Etch Aqueous was used in the flood rinse module.

With both systems being similar in design and using the same chemistries, the issues that were addressed for this activity were

1. Etch uniformity - variation in conductor path widths across the top of the panel, the bottom of the panel, and the difference in the average top and bottom conductor widths;

2. Conductor sidewall integrity - qualitative evaluation of the conductor sidewall characteristics; and

3. Rinse capability - how well the new etcher rinsed off etch residues in the water rinse modules.

Additional attributes reported are conductor and space yields of 0.006 " lines and $0.0055^{\prime \prime}$ spaces and the etch rate for each system. 
Thirty panels were etched for this evaluation. Five panels were etched using the new system and five panels were etched using the old system. This was done three separate times to verify repeatability. Although $12^{\prime \prime} \times 12^{\prime \prime}$ panels were commonly etched in the department, the panels used in this activity were $18^{\prime \prime} \times 24^{\prime \prime}$ in order to be compatible with the conductor analysis artwork and equipment. The panels were polyimide/glass with 1-ounce (0.0014" thick) copper on each side.

The appendix details the processing sequence and some of the important parameters used to fabricate the test panels.

Dry film photoresist was laminated to each side of the panel using a hot roll laminator. An image was patterned in the resist, and the resist was developed in a solution of $1 \%$ sodium carbonate and deionized water. The image on the top of the panel was essentially the same as the image on the bottom having 352 areas (per side) of a variety of conductor and spacing widths. (See Figure 1.) The patterns had conductor widths of 3, 4, 5, and 6 mils. The spaces between the conductors were $3.5,4.5$, and 5.5 mils, respectively. Ten panels were imaged on one day, and the remaining 20 panels were imaged on another day.

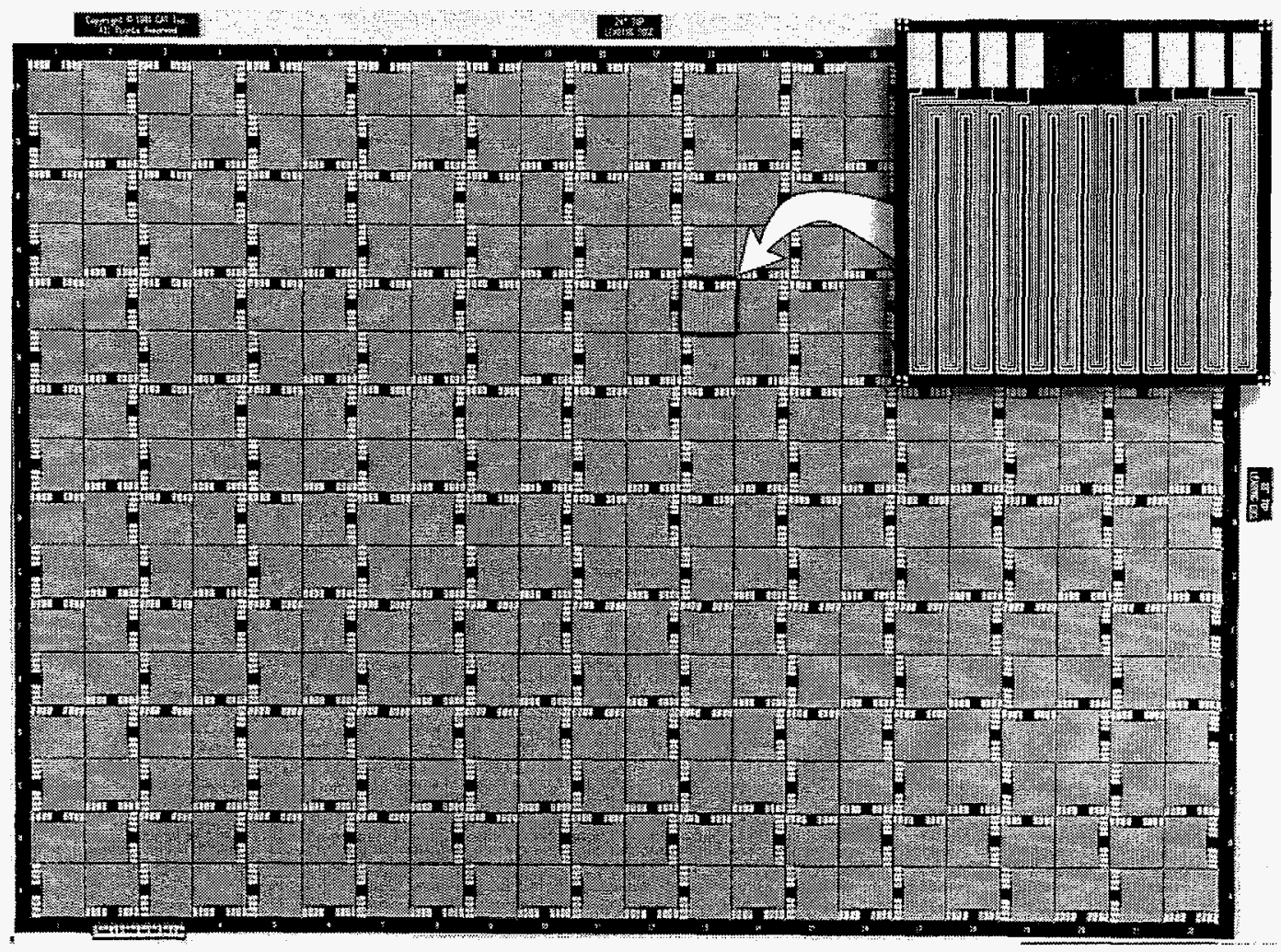

Figure 1. Artwork Used to Image Patterns (From CAT, Inc. ${ }^{1}$, used by permission.) 
The first 10 panels were imaged and etched on August 4, 1995 (five in the Chemcut and five in the Atotech). The remaining 20 panels were imaged on August 8,1995 . Five of the panels were etched in each system on the morning of August 8,1995 . The remaining five were to be etched that afternoon. Both systems were in constant use between the morning and afternoon runs to simulate two separate days; however, the Chemcut system's conveyor was not working that afternoon. The Chemcut Day 3 panels were actually etched on August 18, 1995.

An additional thermal bump was added after exposure on the 20 panels processed for Days 2 and 3. This was done as an attempt to improve the definition and yields of the narrow lines and spaces. Although the conductor analysis data does not indicate an improvement, conductors on the panels which had the thermal bump exhibited straighter, smoother lines.

After etching, the panels were sent to Conductor Analysis Technologies, Inc. in Albuquerque, New Mexico, for electrical conductor analysis testing. Although conductor widths of $0.010^{\prime \prime}$ and wider are standard in the department, data used for this evaluation was taken from measurements of the $0.006^{\prime \prime}$ conductors and the adjacent $0.0055^{\prime \prime}$ space. A complete statistical report was purchased as part of the testing service. All of the data in this report was extracted from the report done by Conductor Analysis Technologies, Inc. except for cross-sectional analysis, scanning electron microscopy (SEM), and ion chromatography, which were done at AlliedSignal Federal Manufacturing \& Technologies (FM\&T) in Kansas City, Missouri.

\section{Upper and Lower Etch Uniformity}

The upper etch uniformity was defined as the standard deviation of the conductor path widths on the top of the panels, and the lower etch uniformity was defined as the standard deviation of the conductor path widths on the bottom of the panels. The average standard deviation of the five panels etched on each system each day are shown in Figure 2. There were differences in spray uniformity between the panel top and bottom, but the differences were slight and consistent from day to day. Note that the bottom uniformity is better. This is most likely due to the puddling effect on the top of the panel as it is conveyed through the etch module.

(Values in mils)

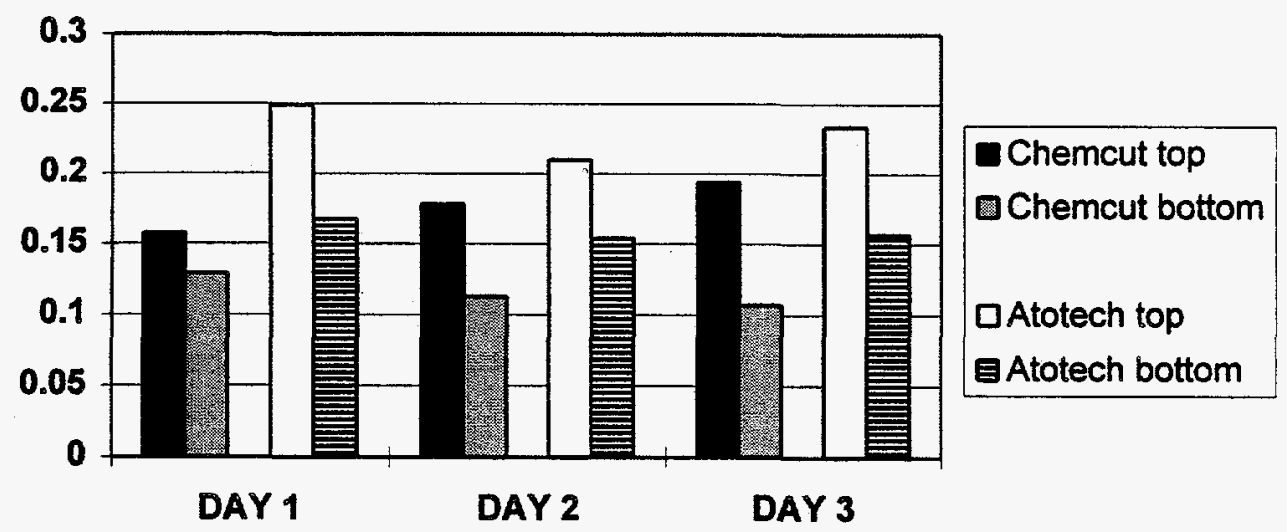

Figure 2. Uniformity of Top and Bottom Conductor Widths 
The Atotech system had adjustable nozzle oscillation capability and an intermittent spray feature to compensate for the effects of puddling. Further characterization will be necessary to fully understand the effects of these added controls.

\section{Spray Uniformity Comparison Between Top and Bottom}

The difference in etch uniformity between the top and bottom of the panels is shown in Figure 3. Values are in mils and represent the difference in the average (from 5 panels) conductor widths on the top of the panels and the average conductor width on the bottom of the panels. The differences in the panels etched on the two systems were insignificant. The Atotech performed as well as the Chemcut.

(Value in mils)

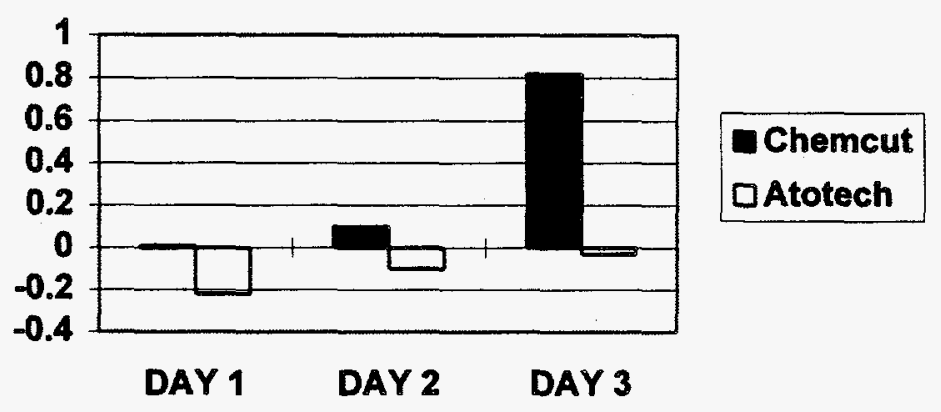

Figure 3. Difference in Average Top and Bottom Conductor Widths

\section{Etched Conductor Sidewall Integrity}

Scanning electron photomicrographs and cross sections of conductor sidewalls were evaluated for a qualitative evaluation of the conductor sidewall slope. Sidewalls of conductors etched on the Atotech system were similar to sidewalls of conductors etched on the Chemcut system. (See Figures 4 and 5.) The cross sections show that the parts etched in the Chemcut system were etched slightly longer because conductors were narrower on the Chemcut parts than those etched in the Atotech system. (See Figures 6 and 7.) 


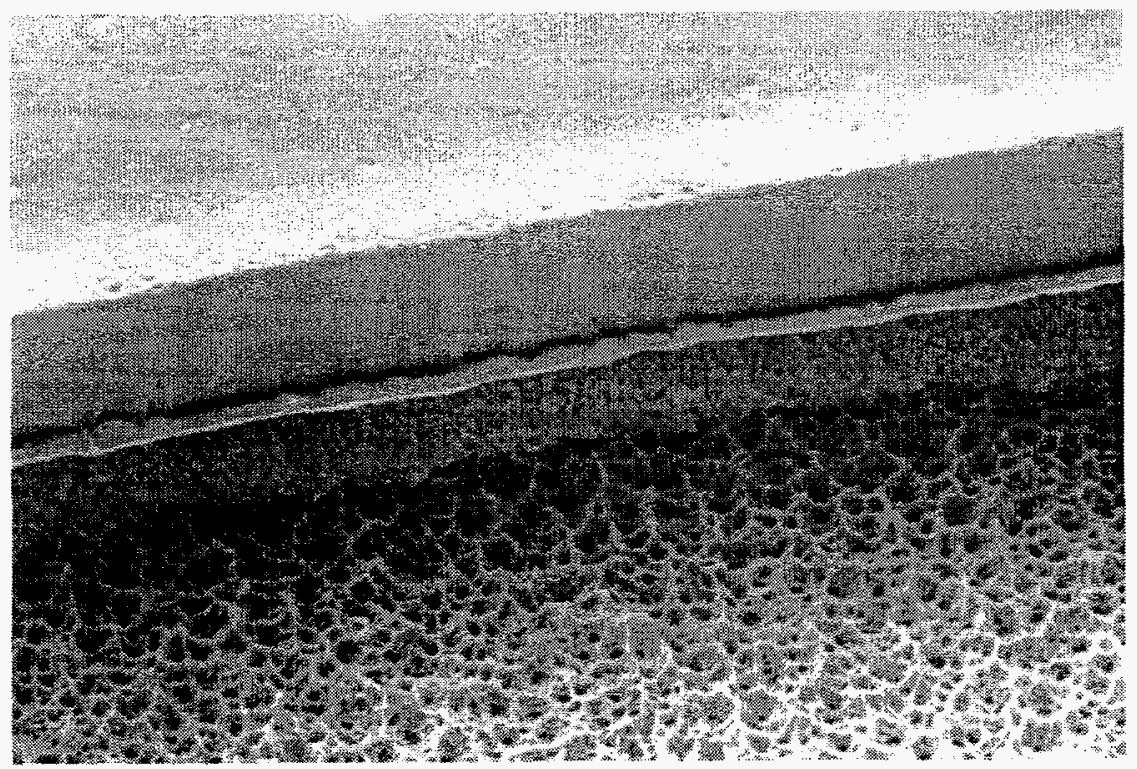

Figure 4. SEM of Conductor Sidewalls Etched in the Chemcut System (500x)

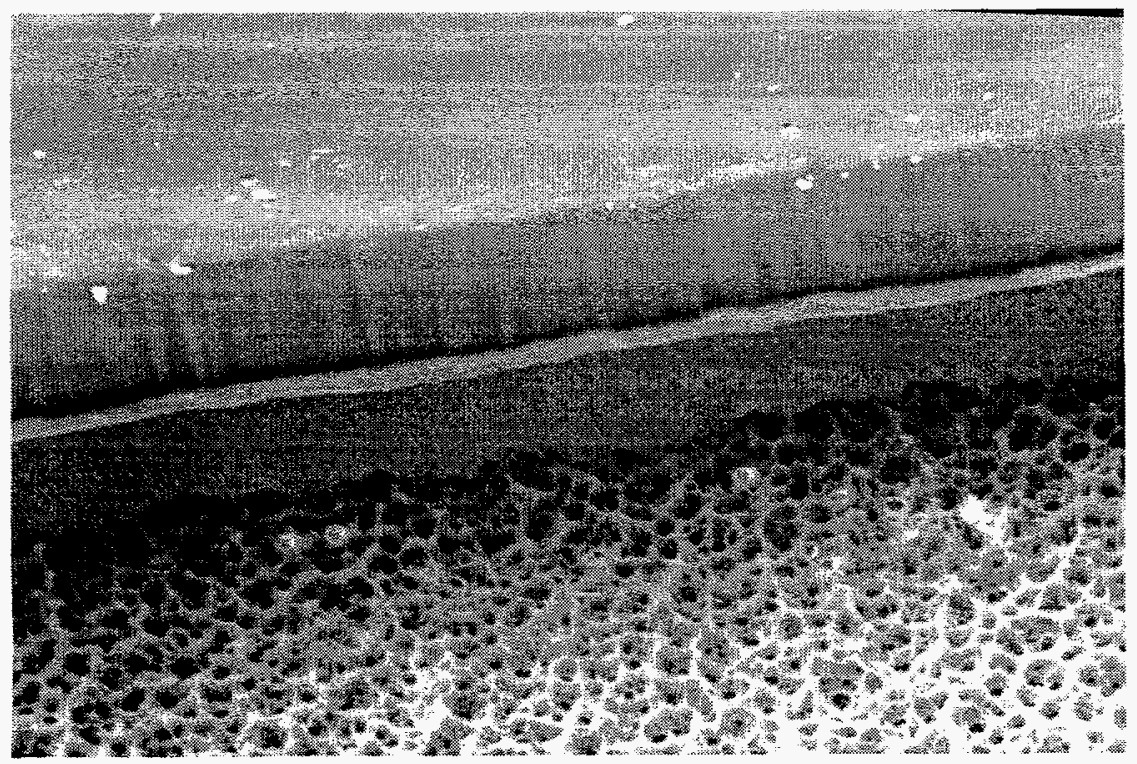

Figure 5. SEM of Conductor Sidewalls Etched in the Atotech System (500x) 


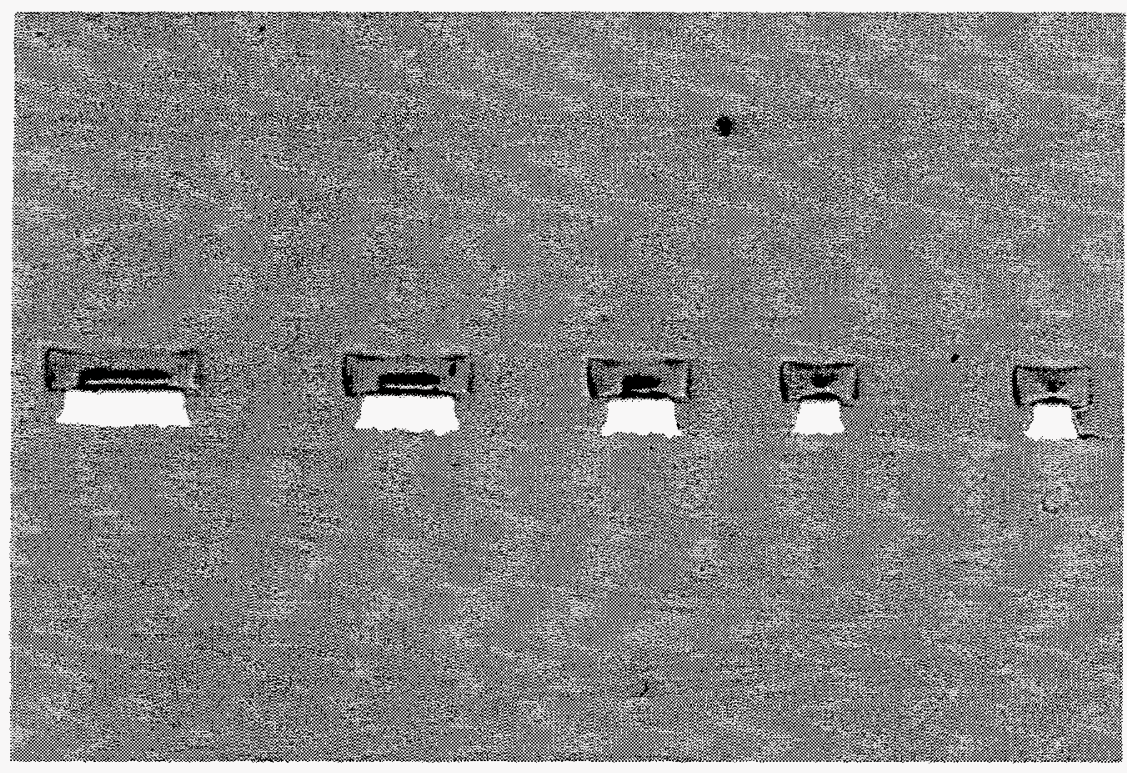

Figure 6. Cross Section of Conductors Etched in the Chemcut System (100x)

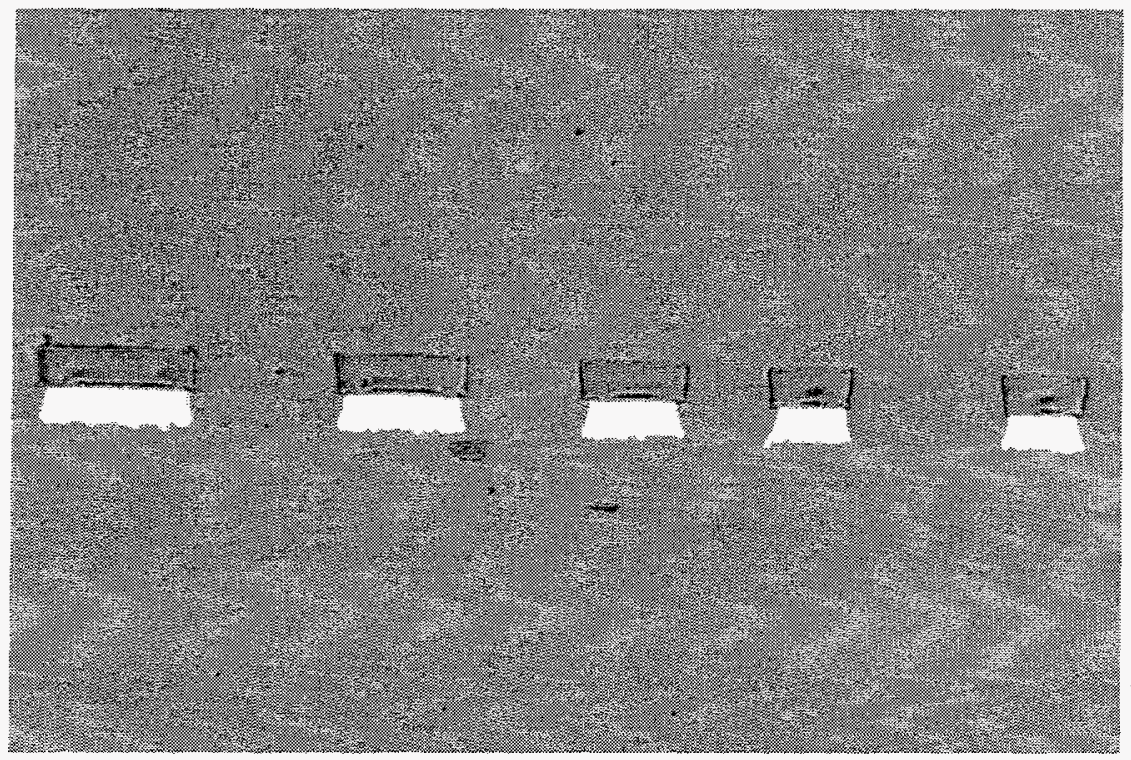

Figure 7. Cross Section of Conductors Etched in the Atotech System (100x) 


\section{Rinse Capability}

The Atotech system had two cascading rinse modules with adjustable water flow rate controls. The flow rates were set at 1 gallon per minute. Coupons from a panel etched on each system were analyzed for etch residues to determine if the rinses were adequate and comparable. The principal residue from etching in the ammoniacal copper chloride chemistry was chloride. Ion chromatography was used to measure the level of chloride ion residue. Figure 8 shows chloride ion residues in micrograms of chloride ions per square inch of surface area. Ion chromatography was not done on other laminates (polyimide flex, polyimide quartz, epoxy glass, and cyanate ester) since the same chemistries were used in both systems. The data indicates that the difference in the two systems is insignificant.

(In micrograms per square inch)

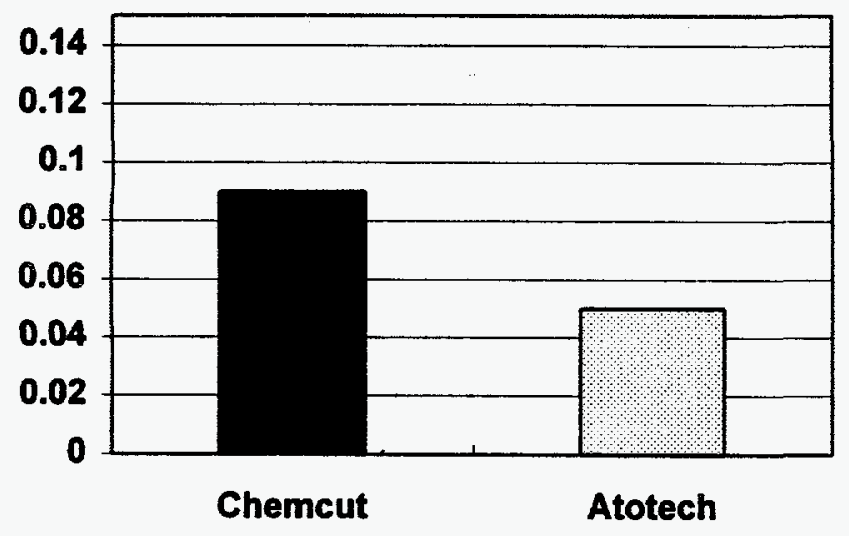

Figure 8. Chloride Ion Residue

\section{Etch Rate}

Panels etched in the Chemcut were etched slightly more than panels etched in the Atotech.

This resulted in better space cleanout between lines and possibly better uniformity on each side of a panel. Figure 9 shows the 5-panel average of the 0.006 " conductor width. A 1-mil etch loss was the target for 1-ounce (0.0014" thick) copper which means that the target conductor width was $0.005^{\prime \prime}$.

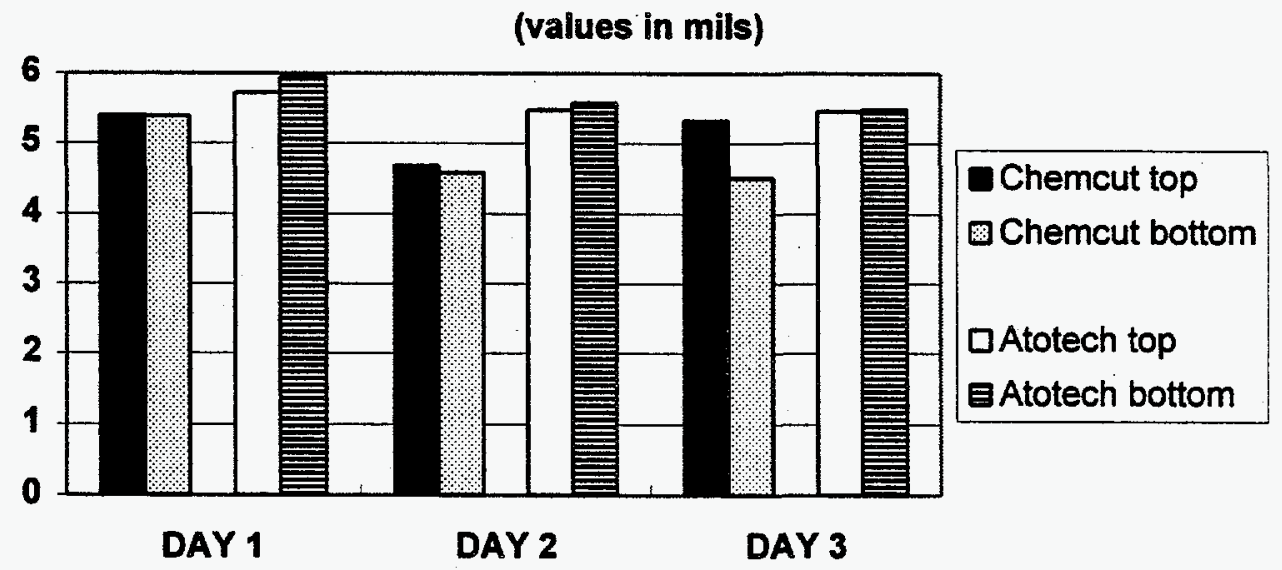

Figure 9. Amount of Etch Beginning With 0.006" Line 


\section{Conductor and Space Yields}

Among the various data collected with the conductor analysis were conductor and space yields. Conductor yield was calculated from the number of opens (breaks) in a known conductor length. Likewise, the space yield was calculated from the number of shorts (bridges) in the spaces between conductors.

Figure 10 shows the comparison of Chemcut and Atotech yields for a given day. The values for conductor yield were calculated from quantity of opens per million inches of 0.006 " conductor length. The values for spaces were calculated from the quantity of shorts per million inches of $0.0055^{\prime \prime}$ space length. The $0.0055^{\prime \prime}$ space was between the 0.006 " line and the adjacent $0.005^{\prime \prime}$ line.

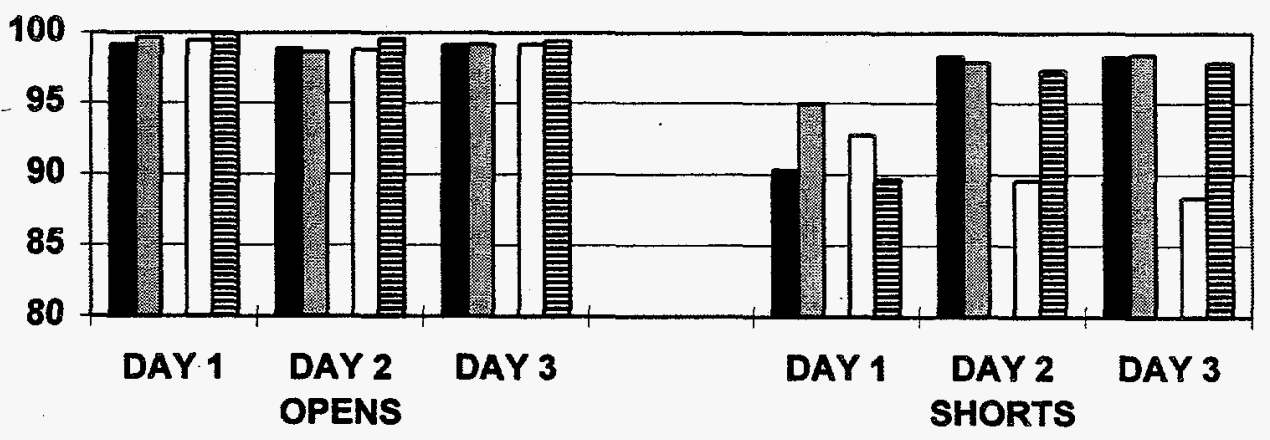

Chemcut top $\square$ Chemcut bottom $\square$ Atotech top $\equiv$ Atotech bottom

Figure 10. Yields of the 0.006 " Lines (Opens) and 0.0055" Spaces (Shorts)

The 0.0055 " space yield was slightly lower for the panels etched using the Atotech system due to the difference in the amount of etch. The Chemcut panels were etched slightly more than the Atotech panels which resulted in better space cleanout. A comparison of Figures 9 and 10 substantiate this. Figure 9 shows that on Day 1 panels received the least amount of etch, and Figure 10 shows that the space yield was the lowest. The greatest amount of etch was on the Chemcut Day 2, and Figure 10 shows the Chemcut space yields were the highest for Day 2.

The photoresist image on the top side of the panels was not as good as the image on the bottom due to lack of experience in exposing small features (less than 0.010 " lines) on $18^{\prime \prime} \times 24^{\prime \prime}$ panels. This was mostly attributed to poor contact between the artwork and the photoresist during exposure. Consequently, excessive photoresist webbing was observed in spaces and resulted in a low space yield. This top-to-bottom difference can be seen especially in the Atotech Day 2 and Day 3 panels. panels, the Atotech system was capable of producing acceptable yields on production product. 


\section{Process Engineering Specification}

A process engineering specification was written and released in August 1995 for operation of the Atotech etch system.

\section{Accomplishments}

A new alkaline etch system was qualified for production use. A process engineering specification (PES) was written to instruct production operators how to use the equipment. 


\section{Reference}

${ }^{1}$ CAT, Inc., Conductor Analysis Technologies, Inc., Albuquerque, New Mexico. 


\section{Appendix}

\section{Processing Sequence and Parameters}




\section{PROCESSING SEQUENCE AND PARAMETERS}

1. CHEMICAL CLEAN - horizontally conveyorized spray cleaner

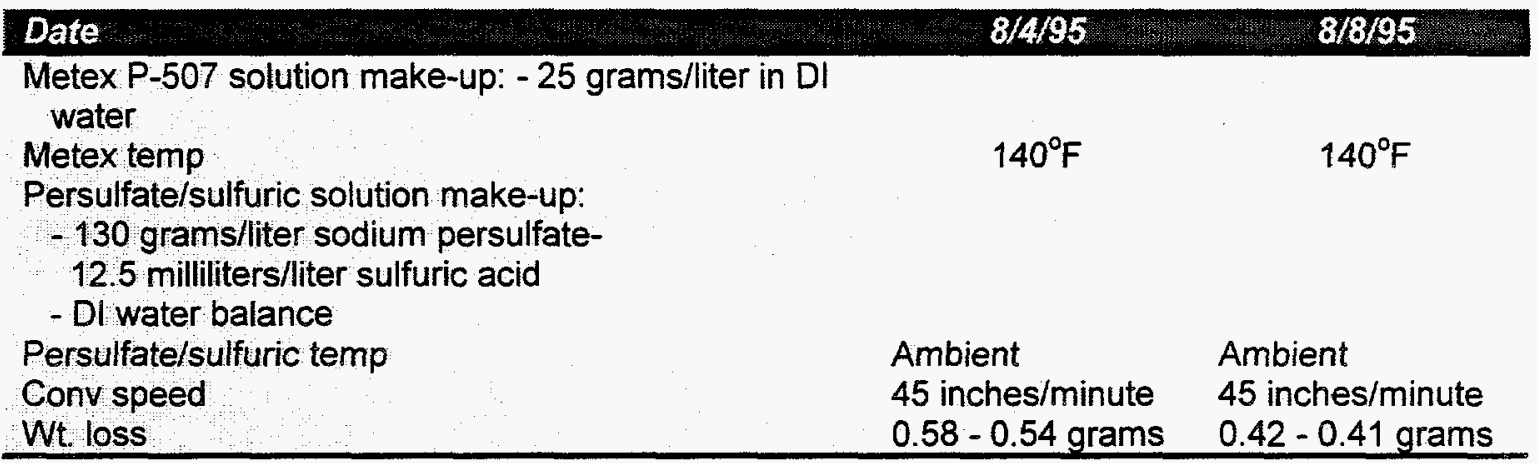

2. MARK - panels were impression stamped with a three-character code. The first character was either the letter $A$ for Atotech or $C$ for Chemcut. The second character was the number 1, 2, or 3, which stood for Day\#1, Day \#2, or Day \#3. The third character represented the panel number (panel 1 through 5). For example:

\begin{tabular}{ll}
\hline MARKING & MEANING \\
\hline A11 & Atotech Day 1, panel 1 \\
A12 & Atotech Day 1, panel 2 \\
C11 & Chemcut Day 1, panel 1 \\
C12 & Chemcut Day 1, panel 2 \\
\hline
\end{tabular}

3. WET BLAST - horizontally conveyorized

4. CHEMICAL CLEAN - same as operation 1

5. LAMINATE RESIST - Hot roll laminator

\begin{tabular}{lll}
\hline Date & \multicolumn{1}{c}{$\mathbf{8 / 4 / 9 5}$} & \multicolumn{1}{c}{$\mathbf{8 / 8 / 9 5}$} \\
Resist type & DuPont's 4615 & DuPont's 4615 \\
Set temperature & $110^{\circ} \mathrm{C}$ & $110^{\circ} \mathrm{C}$ \\
Board exit temp & $131^{\circ} \mathrm{F}$ first, 141 last & $132^{\circ} \mathrm{F}$ first, 133 last \\
Speed & 1.5 meters/minute & 1.5 meters/minute \\
Pressure, air assist for rollers & $27 \mathrm{psi}$ & $27 \mathrm{psi}$ \\
\hline
\end{tabular}




\section{EXPOSE}

\begin{tabular}{lll}
\hline Date & $\mathbf{8 / 4 / 9 5}$ & $\mathbf{8 / 8 / 9 5}$ \\
Step tablet reading & 9 top and bottom & 9 top, 10 bottom \\
Exposure setting & 90 milliJoules $/ \mathrm{cm}^{2}$ & 90 milliJoules $/ \mathrm{cm}^{2}$ \\
Exposure time & 12.6 seconds & 12.8 seconds \\
Artwork & UP36 & UP36 \\
\hline
\end{tabular}

7. THERMAL BUMP (hot roll laminator with no photoresist, Day 2 and Day 3 panels only)

\begin{tabular}{ll|}
\hline Date & $8 / 8 / 95$ \\
\hline Set temperature & $100^{\circ} \mathrm{C}$ \\
Board exit temp & $141-142^{\circ} \mathrm{F}$ \\
Speed & 1.0 meters/minute \\
Pressure & $27 \mathrm{psi}$ \\
\hline
\end{tabular}

8. DEVELOP - $1 \%$ by wt sodium carbonate monohydrate and DI water solution in a horizontally conveyorized spray system.

\begin{tabular}{ll} 
Date & $8 / 4 / 95 \& 8 / 8 / 95$ \\
Solution pH & $10.5-11.5$ \\
Solution temperature & $82^{\circ} \mathrm{F}$ \\
Speed & 2.25 feet/minute \\
Spray pressure & 28 top \& bottom \\
\hline
\end{tabular}




\section{ETCH}

\begin{tabular}{lll}
\multicolumn{1}{c}{$8 / 4 / 95$} & \multicolumn{1}{c}{ Chemcut } & \multicolumn{1}{c}{ Atotech } \\
\hline pH & 7.87 & 8.11 \\
Copper content & 159 grams/liter & 145 grams/liter \\
Temperature & $125^{\circ} \mathrm{F}$ & $125^{\circ} \mathrm{F}$ \\
Chloride & 200 grams/liter & 174 grams/liter \\
Conveyor speed & 42 inches $/$ minute & 38 inches $/$ minute \\
Etch spray pressure & Upper $=12 \mathrm{psi}$ & Upper input $=12 \mathrm{psi}$ \\
& Lower $=20 \mathrm{psi}$ & Upper output $=20 \mathrm{psi}$ \\
& & Lower input $=14 \mathrm{psi}$ \\
& & Lower output $=14 \mathrm{psi}$ \\
\hline
\end{tabular}

\begin{tabular}{lll}
\hline \multicolumn{1}{|c}{ 8/8/95 } & \multicolumn{1}{c}{ Chemcut } & \multicolumn{1}{c}{ Atotech } \\
\hline pH & 7.80 & 7.70 \\
Copper content & 156.80 grams/liter & 160.0 grams/liter \\
Temperature & $125^{\circ} \mathrm{F}$ & $125^{\circ} \mathrm{F}$ \\
Chloride & 199.80 grams/liter & 172.70 grams/liter \\
Conveyor speed & 42 inches $/$ minute & 38 inches $/$ minute \\
Etch spray pressures & Upper $=12 \mathrm{psi}$ & $\begin{array}{l}\text { Upper input }=12 \mathrm{psi} \\
\end{array}$ \\
& Lower $=20 \mathrm{psi}$ & $\begin{array}{l}\text { Upper output }=20 \mathrm{psi} \\
\text { Lower input }=14 \mathrm{psi}\end{array}$ \\
& & Lower output $=14 \mathrm{psi}$ \\
\hline
\end{tabular}

\begin{tabular}{|c|c|c|}
\hline $\begin{array}{l}\text { pH } \\
\text { Copper content } \\
\text { Temperature } \\
\text { Chloride } \\
\text { Convey or speed } \\
\text { Spray pressure }\end{array}$ & $\begin{array}{l}\text { No panels etched } \\
\text { due to equipment } \\
\text { problems }\end{array}$ & $\begin{array}{l}7.70 \\
155.60 \text { grams/liter } \\
125^{\circ} \mathrm{F} \\
172.60 \text { grams/liter } \\
38 \text { inches } / \text { minute } \\
\text { Upper input }=12 \mathrm{psi} \\
\text { Upper output }=20 \mathrm{psi} \\
\text { Lower input }=14 \mathrm{psi} \\
\text { Lower output }=14 \mathrm{psi}\end{array}$ \\
\hline
\end{tabular}

\begin{tabular}{ll}
\multicolumn{1}{c}{$8 / 18 / 95$} & \multicolumn{1}{c}{ Chemcut } \\
\hline pH & 7.80 \\
Copper content & 146.00 grams/liter \\
Temperature & $125^{\circ} \mathrm{F}$ \\
Chloride & 195 grams/iter \\
Conveyor speed & 45 inches $/$ minute \\
Spray pressure & Upper $=12 \mathrm{psi}$ \\
& Lower $=20 \mathrm{psi}$ \\
\hline
\end{tabular}

10. STRIP PHOTORESIST - 3\% potassium hydroxide and DI water in conveyorized spray etch system.

11. CHEMICAL CLEAN - same as operation 1. 